\title{
The Influence of No-till Farming on Durum Wheat Mycorrhization in a Semi-Arid Region: A Long-Term Field Experiment
}

\author{
Hassiba Hadj Youcef Taibi ${ }^{1,6}$, Noria Smail-Saadoun ${ }^{1}$, Sonia Labidi ${ }^{2,5}$, Karima Abdellaoui ${ }^{1}$, \\ Mahfoud Makhlouf ${ }^{4}$, Abdelkrim Laouar ${ }^{3}$, ChérifaTagmount Benouaret ${ }^{1}$, Lila Rezki-Sekhi ${ }^{1}$, \\ Amel Belkebir Boukais ${ }^{1} \&$ Anissa Lounès-Hadj Sahraoui ${ }^{2}$ \\ ${ }^{1}$ Natural Resources Laboratory, Department of Agronomic Sciences, Mouloud Mammeri University, Tizi Ouzou, \\ Algeria \\ ${ }^{2}$ Unit of Environmental Chemistry and Interactions on the Living, UR 4492-UCEIV, University of the Littoral \\ Opale Coast, Condorcet FR CNRS 3417, F-62228 Calais Cedex, France \\ ${ }^{3}$ Faculty of Science of Nature and Life, Ferhat Abbas University, Setif, Algeria \\ ${ }^{4}$ Institute of Field Crops, Agricultural Experimental Station of Setif, Setif, Algeria \\ ${ }^{5}$ Laboratory of Horticultural Sciences, LR13AGR01, Carthage University, National Agronomic Institute of \\ Tunisia, 43 Ave Charles Nicolle, 1082 Tunis, Mahrajène, Tunisia \\ ${ }^{6}$ Department of Agronomy, M'Hamed Bougara University of Boumerdes, Boumerdes, Algeria \\ Correspondence: Hassiba Hadj Youcef Taibi, Natural Resources Laboratory, Department of Agronomic Sciences, \\ Mouloud Mammeri University, Hasnaoua Road, BP 17, 15000, Tizi Ouzou, Algeria. Tel: 213-555-457-726. \\ E-mail: htaibi@hotmail.fr
}

Received: January 8, 2020

Accepted: February 9, $2020 \quad$ Online Published: March 15, 2020

doi:10.5539/jas.v12n4p77

URL: https://doi.org/10.5539/jas.v12n4p77

This research was financed by the Ministry of Higher Education and Scientific Research of Algeria and the Ministry of Agriculture.

\begin{abstract}
Maintaining a reliable and sustainable agricultural production system has become one of the major concerns of producers in arid and semi-arid regions. Simplifying farming techniques and practicing Direct Seedling (DS) could contribute to insure the sustainability of agriculture, preserving the natural resources and the environment. Direct Seedling based on limiting soil plowing has a potential number of benefits, including reduced production costs and soil erosion. Associated with the organic mulch, this technique improves the soil fertility and favors the establishment of root symbioses. Given the importance of the no-till farming techniques, the present research work aims to compare the effects of DS and those of Conventional Seedling (CS) on the evolution of arbuscular mycorrhizal symbiosis in durum wheat (Triticum durum Desf) roots, cultivated in the field for five years. Soil and root samples were collected during three different cropping stages at two different treatments. The results of Arbuscular Mycorrhizal Fungi (AMF) root colonization kinetics have shown an increase in the percentage of arbuscules and a decrease in vesicles for plants sampled from a DS field compared to those from CS. Effects of the DS on the mycorrhizal parameters appears clearly in the fourth year of the experiment and continues in the fifth year, with an arbuscule percentage reaching $80 \%$ in a DS field and not exceeding $21 \%$ in a CS field. Soil

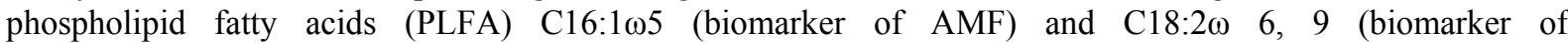
saprophytic/ectomycorrhizal fungi) demonstrate that no-till practice improves AMF biomass and saprotrophic/ectomycorrhizal fungal biomasses by 52 and 159\%, respectively, in comparison with those found in a CS field. In both treatments, no-till farming and CS plots, the AMF biomass is higher than saprotrophic/ectomycorrhizal biomasses. The natural biodiversity of AMF is also enhanced in a no-till field. In addition, an increase in the relative abundance of six families of Glomeromycota (Gigasporaceae, Diversisporaceae, Scutellosporaceae, Entrophosporaceae, Acaulosporaceae, Dentiscutataceae) was observed. To summarize, the present study highlights the importance of no-till practice as an approach to restore the microbiome in soils disturbed by tillage in semi-arid regions.
\end{abstract}


Keywords: arbuscular mycorrhizal fungi, no-till farming, conventionnel seedling, lipid biomarkers, root endophytes, semi-arid region

\section{Introduction}

Maintaining a reliable and sustainable agricultural production system has become one of the major concerns of producers in arid and semi-arid regions (Lyons et al., 1996; Bruelle et al., 2017). Simplifying farming techniques and using no-till techniques contribute to ensure the sustainability of agriculture, preserving the natural resources and the environment. To cope with the various constraints, including drought, many countries around the world (The United States, Argentina, Chile, Brazil, and Australia), have adopted the simplification of cultural techniques, known as SCT (Freitas et al., 2013; Bellotti et al., 2014). In 2007, the extension of this system was about 95 million hectares (Lal et al., 2007), and presently it exceeds 125 million hectares (Bruelle et al., 2017).

In Algeria, cereals are rainfed crops that occupy an annual area of 3.5 million hectares (Rouabhi et al., 2019). They are mainly located in the east of the country, in the semi-arid regions of the High Plateaus, where yearly rainfall levels are less than $400 \mathrm{~mm}$. Soils of these regions are predominantly calcareous with low levels of soil organic matter (Batouche \& Labiod, 1991). The combined effects of all these factors affect cereal production, and yields remain low even though the cultivated varieties are improved (Lahmar \& Ruellan, 2007). Cultivation of cereals is conducted according to the soil conventional tillage system, based mainly on soil plowing to control weeds, preparing seedlings, incorporating residue crops and fertilizers, and increasing water infiltration. Conventional farming system increases grain production costs and threat of soil erosion (about 2000 to 4000 tons $/ \mathrm{km}^{2}$ of soil are lost) (Kaci et al., 2017; Arabi \& Roose, 1989), especially when combined with overgrazing.

Compared to other farming systems, conventional soil tillage (CT) influences the soil physical characteristics. It increases the soil pulverization at $0-10 \mathrm{~cm}$ depth leading to lower bulk density and higher macroporosity, which facilitates water erosion. In layers below $10 \mathrm{~cm}$ depth, CT increases bulk density and reduces the macro-porosity to critical levels for crop growth (Tuzzin de Moraes et al., 2016), which increases the risk of soil compaction, penetration resistance and affects their biological activity (Babujia et al., 2010; Aslam, 1999).

Conservation agriculture (CA) is a more recent innovation that combines soil cover-organic-mulch, reduced plowing or no-till practice and crop rotation. It is currently promoted as a means to reduce soil degradation in the Mediterranean semi-arid areas (Lahmar \& Bouzerzour, 2011). A number of experiments and research results from Spain, Morocco and Tunisia, underlines the prominent role of the organic mulch in the improvements that occur in the soil, and suggest that no-till practice is a plausible alternative to conventional tillage (Mrabet, 2001; Lahmar \& Arrúe, 2007; Lahmar, 2010; Vega et al., 2015). However, the adoption of no-till farming should be done in an integrated approach, allowing good management of rotations, judicious control of weeds, diseases and the attack of herbivores while minimizing the use of chemical inputs (Karuma et al., 2014). This will promote biological activity and microbial biomass in soils (Labreuche et al., 2007). Celik et al. (2011) have specified that no-tillage practices under a semi-arid climate have considerably increased the number of arbuscular mycorrhizal fungi (AMF) spores in the soil. Indeed, for cultivated cereal species, direct seedling promotes interactions between the root system and the symbiotic fungi such as Dark Septated Endophytes (DSE) or AMF (Jansa et al., 2006; Schalamuk et al., 2006; Duponnois et al., 2012).

AMF symbiotic interactions allow the host plant to tolerate abiotic stress through a structural change of the root system and especially by providing them better water and mineral nutritions (Rodriguez et al., 2004; Soka \& Ritchie, 2014; Wu, 2017). Root Dark Septate Endophytes (DSE) are fungi that locate and grow between root tissues (Vega et al., 2008). They are characterized by having dark pigmentation, microsclerotia and melanized septated hyphae that colonizes the epidermis as well as the inter and intracellular root cortex of the host plant (Peterson et al., 2008). Many of these fungi are able to colonize the root cells of plants, promoting growth without causing pathologies (Clay, 2004; Yuan et al., 2010; Vergara et al., 2018). DSE are found worldwide and coexist often with different mycorrhizal fungi (Mandyam \& Jumpponen, 2005, 2008).

In Algeria, only 5,559 ha of cereal areas are converted to no-till farming as a result of sensitization campaigns carried out by agricultural research and development institutions. They encourage farmers to adopt the no-till farming system in order to reduce the environmental and economic costs of agricultural production (Zeghouane et al., 2015, 2016).

Consequently, whilst aiming to compare the effect of no-till farming and conventional seedling systems on two important types of fungal root symbiosis-arbuscular mycorrhiza and dark septated endophytic fungi of durum wheat in a field experiment, the present study lasted five years. 


\section{Material and Methods}

\subsection{Experimental Site}

This study was carried out from 2008 to 2013, at the agronomic experimental station of the Technical Institute of Field Crops (ITGC) of Sétif (latitude, 36 $08^{\prime} \mathrm{N}$; longitude, $5^{\circ} 20^{\prime} \mathrm{E}$ and altitude $962 \mathrm{~m}$. The climate is Mediterranean and semi-arid, characterized by cold wet winters and hot dry summers. During the experiment, the average annual rainfall did not exceed $400 \mathrm{~mm}$ and presented some irregularity in distribution, with large inter-month and inter-annual variations. The dry season was usually noted from May to September (Figure 1).

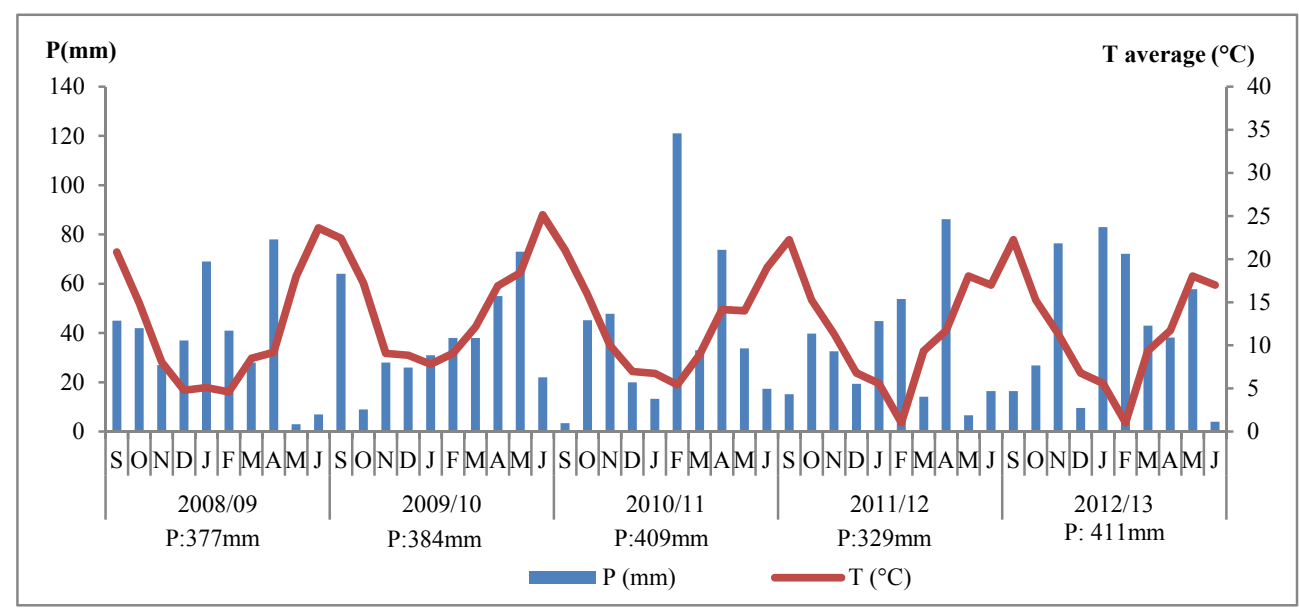

Figure 1. Evolution of precipitation and temperature during the five years of field experimental trial conducted at the agronomic experimental station of the Technical Institute of Field Crops (ITGC) of Setif (ONM National Office of the meteorology).

Soil characterization analyses of the experimental plot were made by the Technical Institute of Field Crops (ITGC) at the beginning of the project. They indicated that on the horizons which delimited the first thirty centimeters of topsoil, the soil of the experimental plot had a clay-sandy-loamy texture, with an average organic matter content of 2.6\%. Basic $\mathrm{pH}(8.26)$ justified the strong presence of total and active limestone $(51.58 \%$; $21.25 \%$ ), which weakened the availability of absorbable phosphorus (7.33 ppm) (Table 1).

Table 1. Physicals and chemicals characteristics of the soil in the experimental field

\begin{tabular}{|c|c|c|c|c|c|c|c|c|c|}
\hline \multicolumn{3}{|c|}{ Physical characteristics \% } & \multicolumn{5}{|c|}{ Chemical characteristics } & \multicolumn{2}{|c|}{ Organic characteristics } \\
\hline Silt & Clay & Sand & $\begin{array}{l}\text { CE } \\
(\mathrm{mmho} / \mathrm{cm})\end{array}$ & $\mathrm{pH}$ & $\begin{array}{l}\text { Total } \mathrm{CaCo}_{3} \\
(\%)\end{array}$ & $\begin{array}{l}\text { Actif } \mathrm{CaCo}_{3} \\
(\%)\end{array}$ & $\begin{array}{l}\text { Available } \mathrm{P}_{2} \mathrm{O}_{5} \\
(\mathrm{ppm})\end{array}$ & $\begin{array}{l}\mathrm{OM} \\
(\%)\end{array}$ & $\begin{array}{l}\text { C org } \\
\left(\mathrm{mg} \mathrm{g}^{-1}\right)\end{array}$ \\
\hline 34.66 & 34.66 & 30.66 & 0.175 & 8.26 & 51.58 & 21.25 & 7.33 & 2.6 & 1.51 \\
\hline
\end{tabular}

Note. Available phosphorus (Olsen Phosphorus) was determined by the Olsen et al. (1954) method.

The soil organic carbon was determined by means of the Anne method.

The total and active carbon dosages were made by the methods of Bernard's calcimeter and that of Drouineau, respectively. Soil Granulometry by the Robinson Method.

\subsection{Plant Material and Field Conditions}

The studied variety of durum wheat used in the present study is named "Boussalem". It was obtained from the Sétif experimental station (Heider/Marli/Heider Cro ICD4141BLCTR4AP) on an ICARDA-CIMMYT introduced material. The experimental design was based on the application of two soil management practices: 1) No-till with seedling (SD) carried out directly in the residue of the previous crop, using a combined seeder (SEMEATO) which opened only a seed line with $2 \mathrm{~cm}$ of width; 2) Conventional seedling (CS), where the soil was prepared with a moldboard plough followed by a cover crop and a disc harrow. Seedling was carried out by means of a conventional seed drill (Figure 2). 


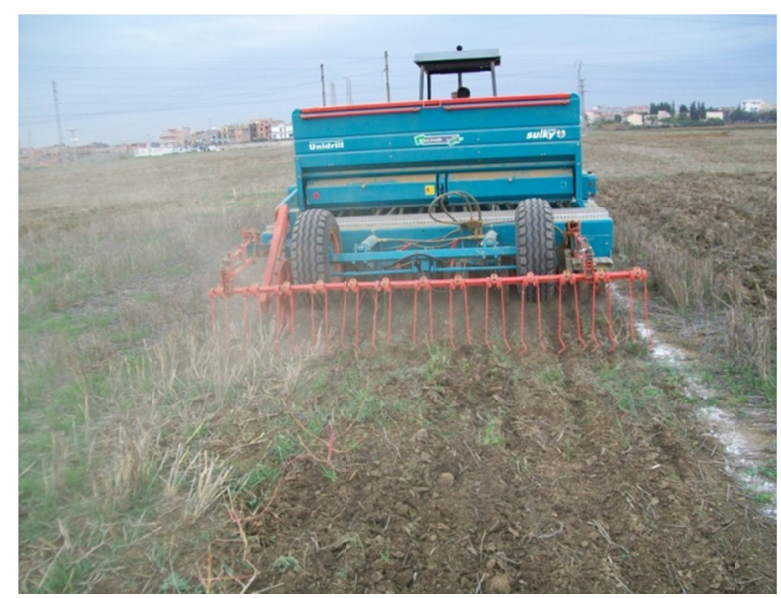

A. Direct Seedling

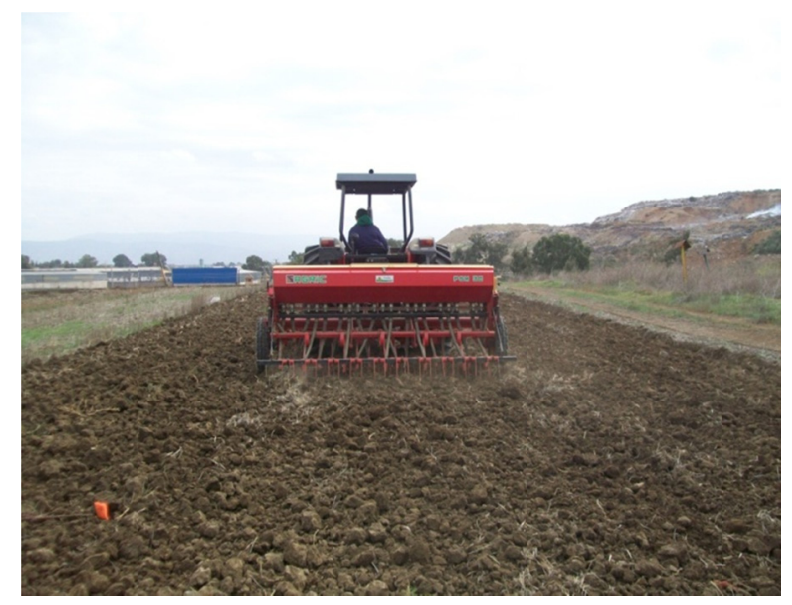

B. Conventional Seedling

Figure 2. Photos of the both seeders used in the experiment

Note. The previous crop is a durum wheat, two treatments are conducted as follows: Direct Seedling (A): No Tillage; Conventional Seedling (B): Mouldboard plough + Cover Crop + disc harrow.

Seedling rate was of $130 \mathrm{~kg} / \mathrm{ha}$. Farming techniques applied on the fields during the five years of the experiment culture are described in Table 2.

Table 2. Culture conditions applied to the plots of the field trial

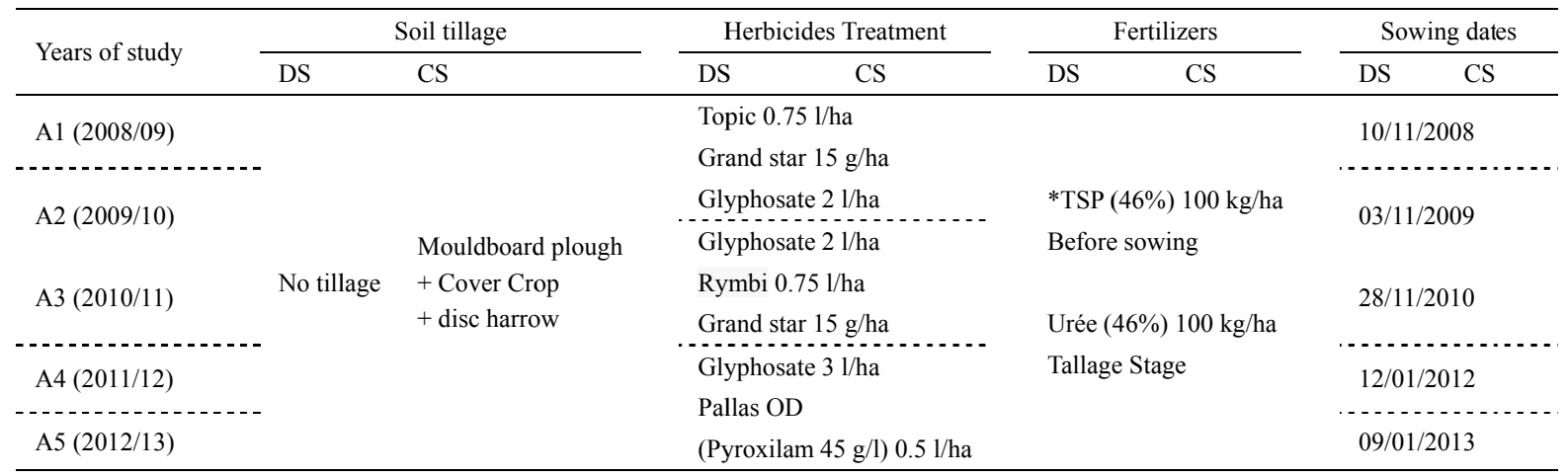

Note. DS: no-till farming system; CS: Conventional Seedling; TSP: Tri Sulfate of Phosphate.

*The high presence of weeds in no-till plots necessitated a total weeding before sowing with glyphosate and at post-emergence with Grand star (anti dicotyledonous) mixed with Brumby (anti monocotyledons) or with Pallas OD (anti dicotyledonous and monocotyledons).

* The conventional seedling trial was only subjected to post-emergence weeding.

* The change of products for the last two campaigns is justified by the appearance of Brome plants (Bromus rubens) which is controlled by the Pallas OD herbicide and not by the other previous products.

For the two treatments, the plots had $180 \mathrm{~m}^{2}$ of area with three replicates per treatment, and they were distributed following a completely randomized bloc design (Figure 3). 


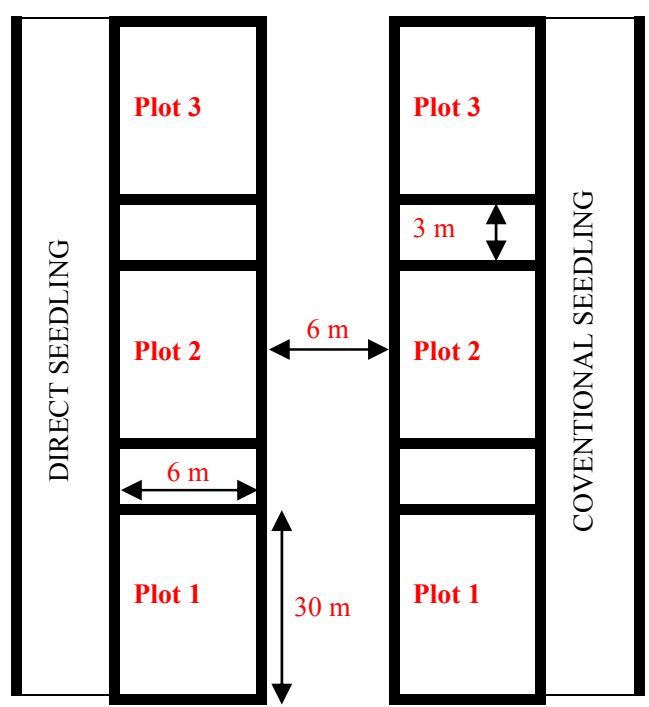

Figure 3. The experimental design applied during the five years of experimentation

Note. Test with six plots with $180 \mathrm{~m}^{2}(6 \mathrm{~m} \times 30 \mathrm{~m})$ arranged as a complete random block (CRB).

\subsection{Plant and Soil Sampling}

The experimental trial was field-installed in 2008, but our observations started in the third year of testing (2010-2011) and proceeded as follows:

\subsubsection{Soil Fatty Acid Analysis}

Two soil samples were taken from each plot at a depth of $10 \mathrm{~cm}$ with an auger, following the harvest of the 2010/2011 trial (third year of application of the two different operating systems). After removing plant debris from soil samples, four replicates of $3 \mathrm{~g}$ of freeze-dried soil (from each soil sample) were analysed to measure the phospholipid fatty acid (PLFA) contents. Amounts of PLFA and neutral fatty acid (NLFA) specific to AMF $(\mathrm{C} 16: 1 \omega 5)$ and to saprotrophic/ectomycorrhizal fungi (C18:2 $\omega 6.9)$ were measured.

Lipid extraction was carried out following the method suggested by Frostegård et al. (1991). The extracted lipids were fractionated into neutral lipids, glycolipids and polar lipids on a silica acid column by successively eluting with chloroform, acetone and methanol $(1: 2: 1, \mathrm{~V}: \mathrm{V}: \mathrm{V})$. Chloroform fraction (containing the neutral lipids) and the methanol fraction (containing the phospholipids) were subjected to a transesterification using a base solution $(\mathrm{KOH} 0.2 \mathrm{M})$ prepared in methanol to transform the PLFA and the NLFA into free fatty acid methyl esters. Final extracts were analysed by using a PerkinElmer Auto system gas chromatograph (GC) equipped with a flame-ionization detector (Norwalk, CT) and an EC-1000 (Alltech) capillary column ( $30 \mathrm{~m} \times 0.53 \mathrm{~mm}$ i.d.) with hydrogen as a carrier gas $\left(3.6 \mathrm{ml} \mathrm{min}^{-1}\right)$. The temperature program included a fast rising from $50{ }^{\circ} \mathrm{C}$ to $150{ }^{\circ} \mathrm{C}$ at $15{ }^{\circ} \mathrm{C} \mathrm{min}-1$ and then a rise from 150 to $220{ }^{\circ} \mathrm{C}$ at $5{ }^{\circ} \mathrm{C} \mathrm{min}{ }^{-1}$. Fatty acid quantification was made by using nonadecanoic acid methyl ester (C19:0) as an internal standard. Their identification relied on the retention times of a wide range of standards (fatty acid methyl ester mixtures C4-C24:1, Sigma Aldrich) and mass analysis. The system was operated in the constant linear velocity $\left(70 \mathrm{~cm} \mathrm{~s}^{-1}\right)$ using helium as a carrier gas. Fatty acids were identified by comparing their mass spectra with the standard mass spectra in the NIST MS library.

\subsubsection{Determination of Arbuscular Mycorrhizal Fungal Colonization}

To estimate the root colonization by AMF, during three stages of the vegetative cycle of wheat (tillering, grain filling and grain maturity), 6 plants/plot/stage for each treatment were sampled in 2011, 2012 and 2013 (last three years of the experiment). The measurement was performed on fresh roots. Roots were soaked during 5 min in an $\mathrm{H}_{2} \mathrm{O}_{2}(30 \%)$ bath to remove pigments, cleared in $\mathrm{KOH}(10 \%)$ and stained with Trypan blue $(0.05 \%)$ (Phillips \& Hayman, 1970). Root mycorrhizal rates were calculated using a magnified grid line intersect method (Mc Gonigle et al., 1990). For each repetition three microscopic slides with ten randomly root fragments $(1 \mathrm{~cm})$ were observed under an optical microscope $(\times 100)$. Intersections were counted in the following categories: negative (no fungal material in root), arbuscules, vesicles and hyphae. This made it possible to quantify the following rates: 


$$
\mathrm{H} \%=(\mathrm{G}-\mathrm{p}) / \mathrm{G} \times 100 ; \operatorname{Arb} \%=(\mathrm{q}+\mathrm{s}) / \mathrm{G} \times 100 ; \mathrm{Ves} \%=(\mathrm{r}+\mathrm{s}) / \mathrm{G} \times 100
$$

where, G: total number of intersections; p: no mycorrhizal structure; q: presence of arbuscules; r: presence of vesicles; s: presence of arbuscules and vesicles.

\subsubsection{Determination of Dark Septated Endophytic Fungal Root Colonization Rate}

The estimation of root colonization was completed in 2013 by the observation of structures specific to dark septated endophytic fungi (DSE). Microscopic observations were performed on the same slides used for AMF but focused on the structures specific to DSE (dark septated hyphae, microsclerotia) in the root cortex and the central cylinder. The rate of DSE (DSE\%) was calculated according to the following formula:

$$
\mathrm{DSE} \%=\mathrm{E} / \mathrm{G} \times 100
$$

where, E: presence of DSE structures; G: total number of intersections, using the method suggested by McGonigle et al. (1990).

\subsubsection{Biodiversity of AMF Species}

Soil samples were collected during the grain filling stage in the last year of the study. Two soil samples were taken from the rhizosphere zone per plot for each treatment. A mixed homogenized sample was made for each plot to form three samples per treatment. AMF spores were extracted from $100 \mathrm{~g}$ of soil using the wet-sieving method (Gerdemann \& Nicolson, 1963) followed by flotation-centrifugation in 50\% sucrose (Dalpé, 1993). The spores were isolated from supernatant on a filter paper and were counted using a stereomicroscope at $\times 40$ magnification to determine the total density of AMF (density of spores per $100 \mathrm{~g}$ of soil collected in each studied plot). Spores were thus classified by spore morphotype (size, color, hyphae) (Gerdemann \& Trappe, 1974) and then mounted in polyvinyl alcohol-lacto-glycerol (PVLG) with or without Melzer's reagent on microscopic slides. Observations were carried out under an optical microscope $(\times 100$ magnification $)$. Identification, based on morphological characters, was performed using the INVAM website: http://invam.wvu.edu. Following identification, AMF species richness was evaluated based on the number of species present in each treatment.

The relative abundance of each species in each treatment was calculated following the method provided by Johnson et al. (1991):

$$
\mathrm{RA} \%=(\mathrm{n} / \mathrm{N}) \times 100
$$

Where, $\mathrm{n}=$ number of identified spores, $\mathrm{N}=$ total number of spores. This made it possible to determine the relative abundance of each spore family.

\subsubsection{Carbon and Nitrogen Stocks}

An analysis of organic matter and mineral nitrogen was performed on the soil samples after harvesting during the last year of the experiment. Two soil samples per plot and replicate were taken from a 10-cm depth for each treatment. The soil organic carbon was determined by means of the Anne method (Aubert, 1978). The quantification of total nitrogen was determined according to the KJELDAHL method (Bremner et al., 1982).

\subsubsection{Grain Yield Evaluation}

The grain yield was determined after harvesting for each plot area, during the five years of testing (Grignac, 1986).

\subsection{Statistical Analysis}

An analysis of variance with a Newman and Keuls test for the comparison of means was applied to the data ( $\mathrm{p}<$ 0.05) with Statbox 2012 software. The Percentage data was transformed by a square root procedure.

\section{Results}

\subsection{Effect of Farming System on Wheat Mycorrhizal Colonization}

The results of the three years of observation showed that the total mycorrhizal rate was about $90 \%$ at the tillering stage and during grain filling. At the grain maturity stage, this rate decreased until reaching $26 \%$ in the last year. However, during this latter stage, no-till treatment showed a higher mycorrhizal root colonization compared to conventional seedling. This increase was about $22 \%$ during the second year of observation, and it reached $45 \%$ during the last year (Figure 4). Arbuscules were higher in plant roots sampled from the no-till farming plots than those from the conventional seeding plots during all the time of the trial. At the second year of observation, the arbuscules reached in no-till plots $65 \%$ and $45 \%$ at tillering and filling stages of the grain, respectively. However, in the conventional seedling system, it did not exceed $25 \%$. While this increase continued during the last year of the experiment until reaching $80 \%$ at tillering stage, it remained stable in conventional seedling (Figure 4). 
Contrary to this evolution, the vesicles were found to have increased in the conventional seedling plots, especially in the grain filling stage (Figure 4).
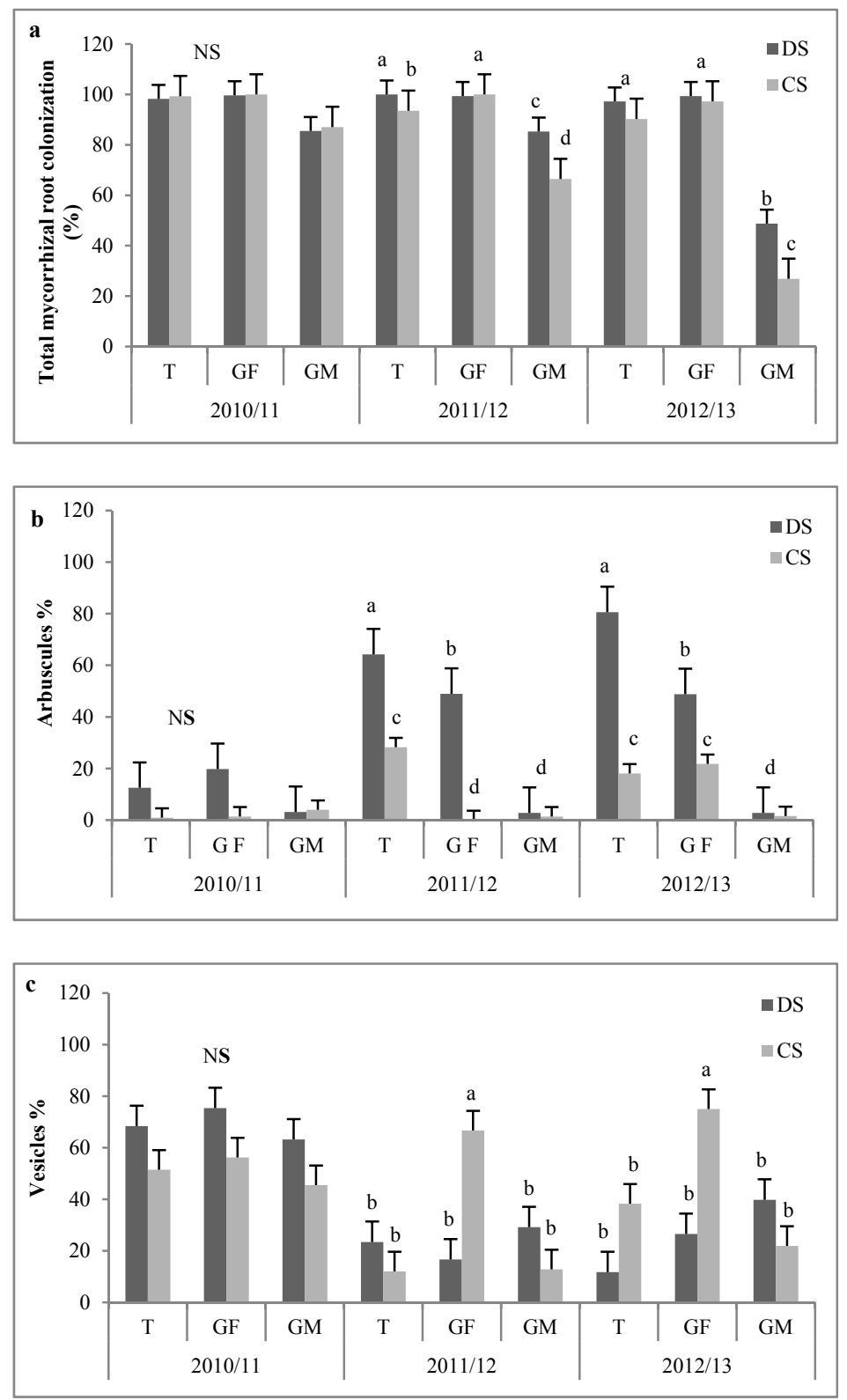

Figure 4. Effect of conventional seedling (CS) and no-till farming system (DS) on total mycorrhizal root colonization (a), abuscules (b) and vesicles(c) percentage during the last three-years of the experiment for the three plant growth stages

Note. T: tillering, GF: grain filling, GM: Grain maturity. Means were obtained from 3 replicates. Significant differences between CS and DS are reported according to the Newman-Keuls test $(\mathrm{P}<0.05)$.

\subsection{Effect of Cultivation System on AMF Diversity}

Spores density varied from 1280 spores to 2114 spores isolated from the soil of conventional and in direct seedling plots respectively. A total of 21 AMF species belonging to 7 families were identified. The AMF richness values of direct and conventional seedling soils were estimated respectively to 85.71 and $66.67 \%$ of the total estimated richness. 
Seven species were found exclusively in direct seedling soil. Among them five species of Acaulosporaceae (Acaulospora scrobiculata; Acaulospora koskei; Acaulospora thomii; Acaulospora capsicula; Acaulospora denticulata) and two species of Gigasporaceae (Gigaspora albida and Gigaspora margarita) with respective relative abundance (38 and 33\%) for two families. Three species of Glomeraceae (G. mossae, G. aggregates and G. ambisporum) were occurred only in the conventional seedling soil.

Eleven species were present in both treatments but more abundant in plots conducted in the no-till system (Figure 5). The respective relative abundance in DS/CS was as follows: Gigasporaceae (13.4\%/7.4\%) with one species (Gigaspora decipiens); Diversisporaceae (12.8\%/5.5\%) with the species Diversispora tortuosa; Scutellosporaceae $(24 \% / 10.5 \%)$ with the species Scutellospora scutata and Scutellospora calospora and Entrophosporaceae (15.6\%/3.7\%) with Entrophospora infrequens. Dentiscutataceae were rarely present in the conventional seedling plots and are poorly present in the no-till plots $(7.8 \% / 0.2 \%)$ with Dentiscutata erythropa and Dentiscutata nigra. Glomeraceae had a dominant presence in the soil of both treatments, but their relative abundance is higher in conventional seedling $(58.7 \% / 76.6 \%)$ with (G. intraradices; G. fasciculatus; $G$. gerdemannii and G. multicaule) (Table 3 and Figure 5).

Table 3. AMF spore species isolated from the soil of the experimental field plots, for each treatment (DS: no-till farming system; CS: conventional seedling) in the last year of the trial

\begin{tabular}{|c|c|c|}
\hline Family/Species & DS & $\mathrm{CS}$ \\
\hline \multicolumn{3}{|l|}{ Glomeraceae } \\
\hline G. intraradices & $\mathrm{x}$ & $\mathrm{x}$ \\
\hline G. fasciculatus & $\mathrm{x}$ & $\mathrm{x}$ \\
\hline G. gerdemannii & $\mathrm{x}$ & $\mathrm{x}$ \\
\hline G. multicaule & $\mathrm{x}$ & $\mathrm{x}$ \\
\hline G. mossae & & $\mathrm{x}$ \\
\hline G. aggregates & & $\mathrm{x}$ \\
\hline G. ambisporum & & $\mathrm{x}$ \\
\hline \multicolumn{3}{|l|}{ Acaulosporaceae } \\
\hline A. koskei & $\mathrm{x}$ & \\
\hline A. thomii & $\mathrm{x}$ & \\
\hline A. capsicula & $\mathrm{x}$ & \\
\hline A. denticulata & $\mathrm{x}$ & \\
\hline A. scrobiculata & $\mathrm{x}$ & \\
\hline \multicolumn{3}{|l|}{ Gigasporacae } \\
\hline Gg. Albida & $\mathrm{x}$ & \\
\hline Gg. margarita & $\mathrm{x}$ & \\
\hline Gg. decipiens & $\mathrm{x}$ & $\mathrm{x}$ \\
\hline \multicolumn{3}{|l|}{ Dentiscutataceae } \\
\hline D. erythropa & $\mathrm{x}$ & $\mathrm{x}$ \\
\hline D. nigra & $\mathrm{x}$ & $\mathrm{x}$ \\
\hline \multicolumn{3}{|l|}{ Diversisporaceae } \\
\hline D. tortuosa & $\mathrm{x}$ & $\mathrm{x}$ \\
\hline \multicolumn{3}{|l|}{ Scutellosporaceae } \\
\hline S. scutata & $\mathrm{x}$ & $\mathrm{x}$ \\
\hline S. calospora & $\mathrm{x}$ & $\mathrm{x}$ \\
\hline \multicolumn{3}{|c|}{ Entrophosporaceae } \\
\hline E. infrequens & $\mathrm{x}$ & $\mathrm{x}$ \\
\hline
\end{tabular}




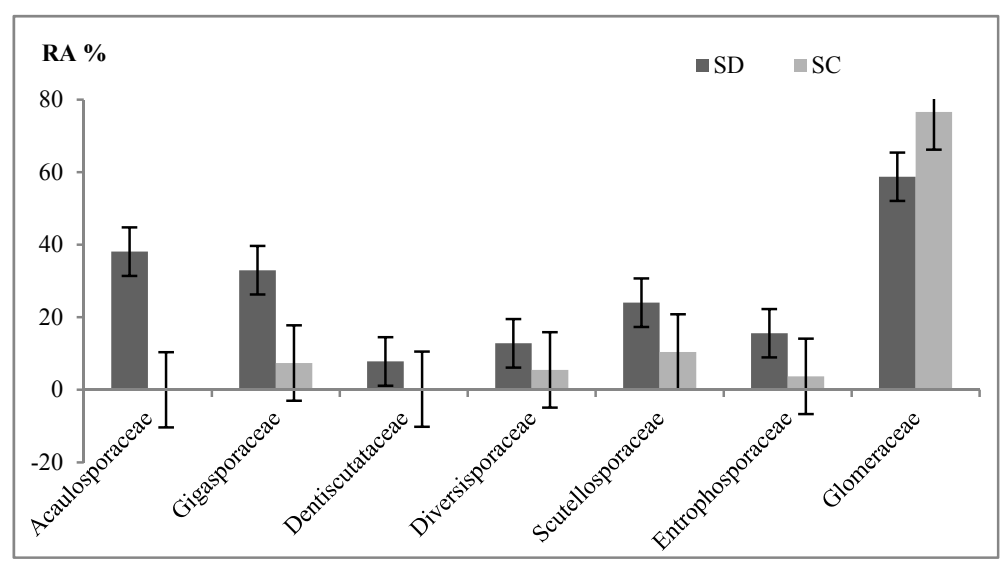

Figure 5. Influence of conventional seedling (CS) and no-till farming system (DS) on the relative abundance (RA\%) of Glomales families. Means were obtained from 3 replicates

\subsection{Arbuscular Mycorrhizal Fungi and Dark Septate Endophytic Root Colonization}

The comparative measurement of wheat root colonization by symbiotic structures specific to AMF and those of dark septate endophytic fungi (DSE) showed that mycorrhizal colonization remained more important in both treatments in comparison with DSE root colonization. The latter reached $40 \%$ in conventional seedling and $57 \%$ in the no-till farming plots, while AMF root colonization exceeded $90 \%$ in both treatments (Figure 6).

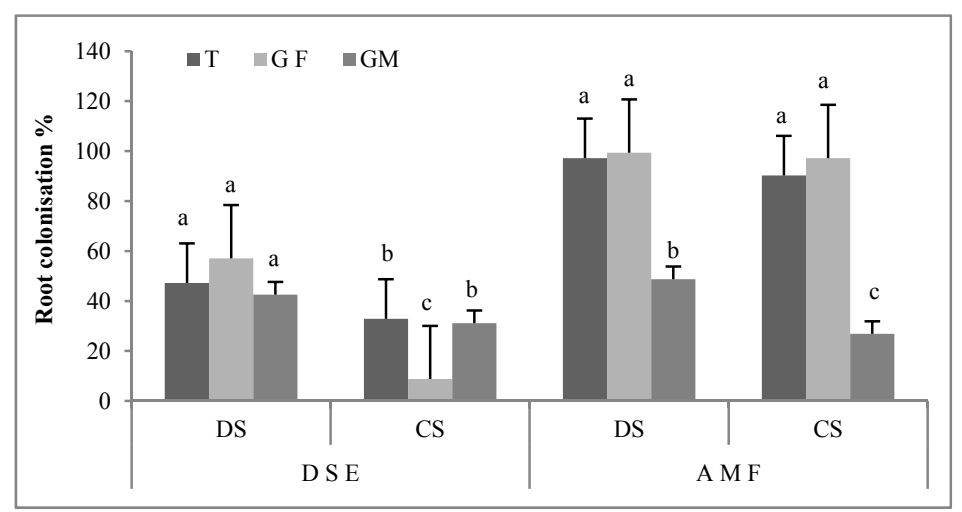

Figure 6. Influence of conventional seedling (CS) and no-till farming system (SD) on mycorrhizal and dark septated endophytic fungi root colonization, after five years of experimentation for the principal stages of plant growth

Note. T: tillering, G F: grain filling, GM: Grain maturity. Means were obtained from 3 replicates. Different letters indicate significant differences between DS and CS according to the Newman-Keuls test $(\mathrm{P}<0.05)$.

\subsection{Effect of the Farming System on Soil Fungal Biomass}

Quantification of microbial biomass by means of specific lipid biomarkers showed that the amounts of PLFA C16:1 $\omega 5$, a specific fatty acid of AMF, increased by $52 \%$ in the no-till plots (DS) compared to the conventional seedling ones with respective values of (DS 1.07/CS 0.70) nanomoles $\mathrm{g}^{-1}$ of soil. Similarly, the amount of PLFA C18:2 $\omega 6.9$ used to quantify saprotrophic and ectomycorrhizal fungal biomasses increased by $159 \%$ with respective values of (DS 0.96/CS 0.37) nanomoles $\mathrm{g}^{-1}$ of soil. C16:1 105 PLFA amounts were higher than C18:2 106.9 PLFA both in the no-till and conventional seedling plots (Figure 7). In contrast, the content of C16:1 $\omega 5$ NLFA representing mainly the storage structures of the AMF (vesicles and spores) was almost the same for both treatments: 1.6 nanomoles/g of soil.

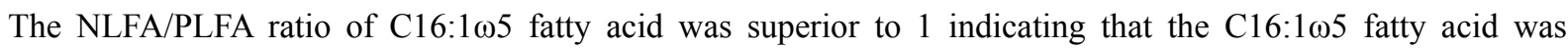
originating from AMF and not bacteria. 


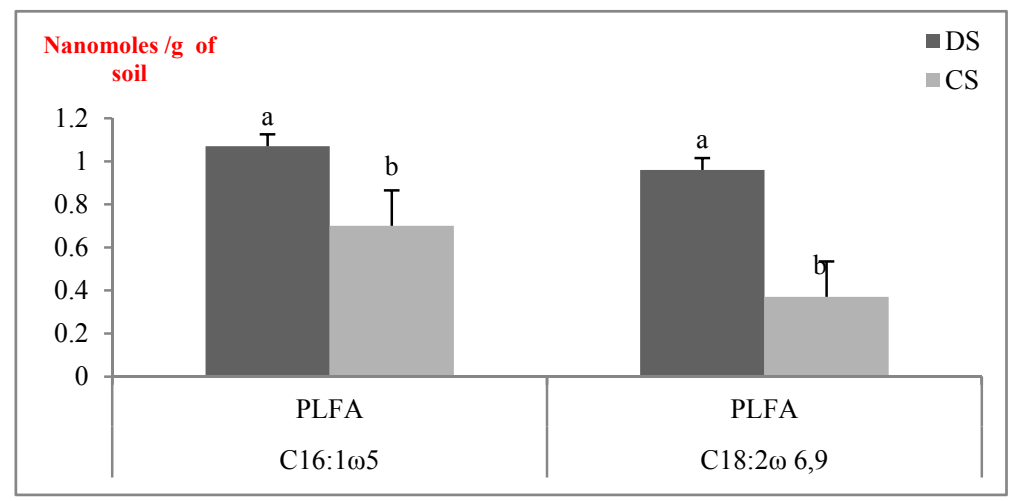

Figure 7. Amounts of phospholipid fatty acid (PLFA) (C16.1w5) specific to AMF and (C18:2 w 6,9) specific to saprotrophic/ectomycorrhizal fungi in root-free soil in no-till farming system (DS) and conventional seedling

(CS), after three years of experiment. Means were obtained from 6 replicates. Different letters indicate significant differences between DS and CS according to the Newman-Keuls test $(\mathrm{P}<0.05)$

\subsection{Organic Matter and Nitrogen Amounts in the Soil}

The results showed that after five years of no-till farming, the soil organic matter and organic carbon contents increased by $29 \%$ compared to conventional seedling. However, this increase was statistically insignificant, and the soil organic matter (SOM) remained low for respectively the no-till and conventional seedling systems (3.71 and $2.62 \%$ ) (Figure 8 ). The mineral nitrogen content remained similar for the two cultural systems $(0.17 \%)$ (Figure 8 ). The $\mathrm{C} / \mathrm{N}$ ratio was improved by $27 \%$.

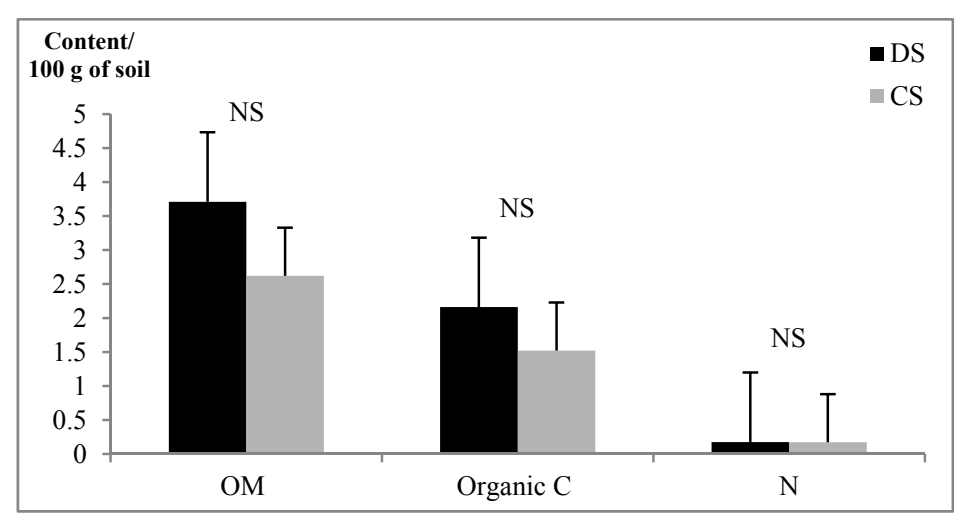

Figure 8. The effect of conventional seedling (CS) and no-till farming (DS), after five years of experimentation, on soil organic matter organic carbon and nitrogen amounts. Means were obtained from 3 replicates. (NS) No significant differences between DS and CS according Newman-Keuls test $(\mathrm{P}<0.05)$ were observed

\subsection{Grain Yields}

In the first three years of the experiment, the wheat grain yield was higher in plots conducted in the direct seedling system compared to the conventional seedling system (Figure 9). The recorded grains are 1.6; 3.6 and 3 t/ha respectively for the three years of trial. However, in the last two years, cereal yields were similar for both systems. 


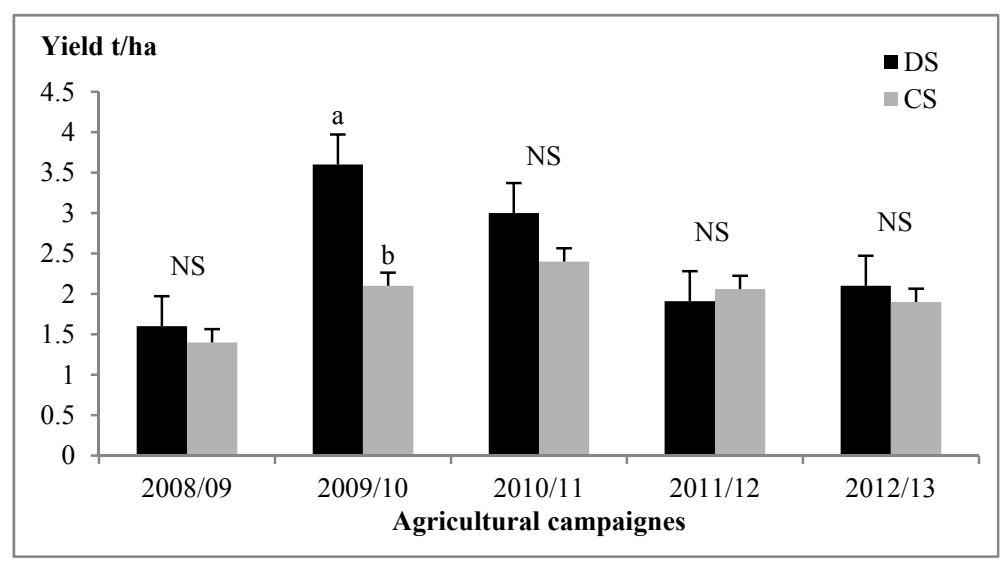

Figure 9. Wheat grain yield during the five years trials in no-till farming system and in conventional one. Means were obtained from 3 replicates. Different letters indicate significant differences between DS and CS according to the Newman-Keuls test $(\mathrm{P}<0.05)$

\section{Discussion}

This long-term study of durum wheat rainfed crop in the east of Algeria, in no-till farming and in the conventional seedling system, has allowed us to determine the effect of these two farming systems on the establishment of a mycorrhizal symbiosis and the diversity of AMF in the field.

After three years of no-till practice, the amounts of PLFA biomarkers (C16:1 $\omega 5$ for AMF) showed an increase in AM fungal biomass in the soil compared to those found in the conventional plots (Figure 7). This reflects a better growth and establishment of extra-radical AMF mycelium (Olsson et al., 1998). Alguacil et al. (2008) reported that the persistence of AM fungi in the soil depends on the survival of their active propagules (e.g. spores, hyphens, colonized roots). Our findings are in agreement with those of Roldan et al. (2007) who observed the highest levels of mycorrhizal propagules in the soil of maize and bean crops without tillage compared to tillage soils.

Under the same conditions, an improvement of saprotrophic and ectomycorrhizal fungi biomass was observed

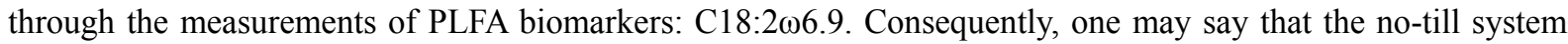
promotes the presence of a mulch of crop residues on the soil surface over a thickness varying from 5 to $30 \mathrm{~cm}$, which may cause the increase in the biomass of the microbial community (Aslam et al., 1999; Balota et al., 2004; Babujia et al., 2010; Kabiri et al., 2016). On the other hand, tillage in conventional seedling causes a dilution of the organic matter and disturbs the fungal mycelium biomass. Our results are consistent with those reached by Bourgeois et al. (2015) and Lienhard et al. (2014), who claim that stopping tillage avoids physical disruption of mycelial hyphae and preserves microbial habitat.

Mycorrhizal and saprophytic fungi constitute the major component of the microbial community of unplowed soils or those with reduced soil tillage (Fontaine et al., 2003). The most intensively managed soils have the highest relative abundance of bacteria and actinobacteria (García-Orenes et al., 2013).

Our results showed that AMF biomass was higher than saprotrophic and ectomycorrhizal biomasses in both no-till farming and conventional seedling plots. Similar findings have been reported by Olsson et al. (1999) in cultivated soils. Van Groenigen et al. (2010) have shown, using both ergosterol and PLFA analyses, that while reduced tillage increased biomass of saprotrophic fungi in the $0-5 \mathrm{~cm}$ soil layer, it increased AMF biomass across the whole plough layer. The aridity of the study area (a rainfall close to $400 \mathrm{~mm}$ ) may explain the dominance of the AMF biomass (Rodriguez et al., 2004; Duponnois et al., 2012; Nadji et al., 2017). Similarly, some characteristics of the study area soil such as the low total phosphorus level (Nadji et al., 2017) and the alkaline soil $\mathrm{pH}$ in relation with limestone mother rock (Djebaili et al., 1984; Halitim et al., 1988) also contributes to the AMF installation. Coutinho et al. (2015) reported that low levels of phosphorus allow production by AMF of a large number of propagules in an environment with few nutrients. This highlights the adaptation of endogenous mycorrhizal fungi strains to the soil physicochemical characteristics (Meglouli et al., 2018). Moreover, the monoculture facilitates the AMF installation because the presence or absence of host plant is important in the occurrence of colonization and sporulation of AMF (Cavalcante et al., 2009; Coutinho et al., 2015). 
The root colonization also demonstrated a predominance of the number of intra-radicular structures specific to AM compared to the dark septated endophytic fungi (Figure 6). This is in accordance with the work of Jansa et al. (2006), who have observed a competitive effect of mycorrhizal fungi on non-mycorrhizal fungi and have claimed that this effect is promoted by reduced tillage. Olsson (1998) maintains that there is a negative impact of AMF on the growth of saprotrophic fungi in calcareous dune sand. However, Keenan et al. (2007) and Liu et al. (2011) showed that the presence of saprotrophic fungi in Gramineae crops reduced the density of AMF spores in the soil and mycorrhizal root colonization could be decrease by $50 \%$.

The emergence of arbuscules in the root cortex of the no-till farming plants at the fourth year of this experiment is likely to reflect a good AMF activity, as put forward by Jansa et al. (2006) and Curaqueo et al. (2010). Their significant positive evolution from the early stage to the last year of the vegetative cycle demonstrates the efficiency of no-till farming in comparison with the conventional seedling system (Figure 4). In fact, arbuscules are the main symbiotic structures ensuring the exchanges between both symbiotic partners (Brundrett et al., 1996, Balestrini et al., 2015).

In our experiment, we observed a large production of vesicles in the cortical compartments of the plant roots grown under the conventional seedling system. The vesicles are carbon storage structures in particular lipids, obtained from the host plant (Brundrett et al., 1996; Olsson, 1999, Trépanier et al., 2005). Vesicle formation is abundant at the end of the growth cycle of the host plant (Al-Karaki et al., 2004). It is a mean of conservation and propagation of fungi (Staddon \& Fitter, 2001). At this stage, AMF will be disconnected from the root of their host plant and deprived of their usual source of energy, thereby catabolising the lipids stored in the vesicles (Olsson, 1998). Under the conditions of the conventional sowing system, the vesicles formation occurred at the grain filling stage reflected a negative partnership between the host plant (durum wheat) and the AMF.

AMF are obligate biotrophs and constitute a strong sink for plant carbon (Gavito et al., 2019) they take advantage of $3 \%$ to $20 \%$ of the carbon substances produced by the host plant (Strullu et al., 1991; Smith \& Read, 2008; Garbaye, 2013). These reserves stored in the vesicles will allow the AMF to develop extended extraradical hyphal networks for efficient soil exploration (Keymer et al., 2017). The growth of the mycelial networks requires a large amount of energy and carbon building blocks, which are transported mostly as lipid droplets and glycogen to the growing hyphal tips (Bago et al., 2002, 2003). The destruction of the hyphal network by tillage explains the high presence of vesicles in the roots of plants growing under the conditions of conventional seeding.

AMF biodiversity studied in the last year of the trial showed the positive effect of no-till farming on the values of spore density and total species richness. Several studies reported the effect of soil tillage on the diversity and structure of AMF in temperate (Jansa et al., 2002, 2003), tropical (Boddington \& Dodd, 2000) subtropical (Alguacil et al., 2008) and Mediterranean soils (Brito et al., 2012). Our findings are in agreement with these studies indicating that intensification of agriculture practices affects negatively AMF abundance and diversity.

The twenty-one species belonging to the seven families of Glomales recorded in the soil of the experimental plot reflect a high AMF diversity. Nadji et al. (2017) reported the importance of diversity and abundance of mycorrhizal propagules in the eastern wheat fields of Algeria. However, a specific richness is observed in the no-tillering treatment soil, linked mainly to the presence of five species of Acaulosporaceae (Acaulospora scrobiculata; Acaulospora koskei; Acaulospora thomii; Acaulospora capsicula; Acaulospora denticulata) and two species of Gigasporaceae (Gigaspora albida and Gigaspora margarita) which completely disappeared in conventional seedling. Similarly Jansa et al. (2006) have reported that, after thirteen years of non-tillage testing, there is the presence of some species of AMF, especially those not belonging to the genus Glomus such as Acaulospora paulinae. Soka and Ritchie (2014) have explained that the hyphae of Acaulospora laevis completely lose their infectivity when the soil is disturbed.

In the Grime's classification of functional groups (Chagnon et al., 2013), the Acaulosporaceae family corresponds to the stress-tolerant AMF which produce less extraradical hyphae and intraradical root structures as compared to Glomeraceae and Gigasporaceae (Maherali \& Klironomos, 2007; Chagnon et al., 2013) which may reduce the exposure to abiotic factors (i.e. drought, salinity, heavy metals, acidity) (Chagnon et al., 2013). These AMF are capable to complete their life cycle producing low biomass, which disappears under plowing in the conventional seedling soil.

Seven species were present in both treatments but more abundant in plots conducted in the no-till system. This is the case of (Gigaspora decipiens; Diversispora tortuosa; Scutellospora scutata; Scutellospora calospora; Entrophospora infrequens; Dentiscutata erythropa and Dentiscutata nigra). This finding is in line with the study of Jansa et al. (2006) which reported that Scutellospora pellucida and Entrophospora infrequens were most 
abundant in no tilled soils. The work of Alguacil et al. (2008) showed an interaction between the tillage system and the host plant showing very significant differences between AM fungal populations for different managed tillage systems. They concluded that no-tillage system had in fact a higher number of fungal types colonizing bean and sorghum crops than the other management.

Spore diversity may also be related to root density which increases favorably under no-till conditions (Cardoso et al., 2003). Similarly, the more abundant weeds in direct seedling (Karkour, 2012) can be an intermediate host between AMF and the main crop (Kabir, 2005).

The Glomeraceae are predominant in both treatments, but their relative abundance was higher in conventional seedling. Three species of Glomeraceae (G. mossae, G. aggregates and G. ambisporum) were occurred only in the conventional seedling soil. The predominance of spores belonging to the family of Glomeraccae has also been recorded in some countries of Africa, particularly in the semi-arid zones of Senegal (Diallo et al., 1999) and Burkina Faso (Guisson, 2001). Schalamuk et al. (2006) have noted that Glomeraceae were more abundant in the conventional system, compared to the no-till farming system. The ubiquity of Glomeraceae family in disturbed environments is related to their ability to grow fast (de Souza et al., 2005), to sporulate rapidly and to restore a network of hyphae by quickly forming anastomoses between the different mycelial branches of the same or neighboring genotype (Giovannetti et al., 1999; Oehl et al., 2003; de la Providencia et al., 2005; Voets et al., 2006). They are therefore considered ruderales AMF (Van der Heijden \& Scheublin, 2007).

Most Glomeraceae have been classified on the basis of their life-history strategies (LHS) as r-strategist because they invest mainly in the production of many offspring, favoring their development in unstable environments (IJdo et al., 2010). In this sense (Johnson et al., 1992; Wang et al., 2008) reported in the tillage soil system, the plowed horizon is mainly occupied by AMF species less useful for crops and investing a large part of their resources in the production of spores.

In addition, Glomeraceae colonize via fragments of mycelium or mycorrhizal root pieces, and therefore have the ability to high root colonization and to develop larger extraradical hyphae (Declerck et al., 2001). In contrast, Gigasporaceae invest more energy in the production of extraradical biomass than in intraradical fungal structures (Hart et al., 2002; Maherali \& Klironomos, 2007), they produce few and large spores (Johnson et al., 1992, de Souza et al., 2005; Wang et al., 2008) and propagate via sporal dispersal or infection from an intact mycelium (Biermann \& Linderman, 1983, Daniell et al., 2001). Such differences clearly explain the dominance of Glomeraceae over Gigasporaceae in environments characterized by repeated severe physical disturbances, such as tillage agricultural practices and clearly explain the loss of species richness of Gigasporaceae by the deep burial of their propagules following the plowing (Oehl et al., 2004) (Jasper et al., 1991; Hart \& Reader, 2004).

The presence of plant residues (mulch) contributes in the increase of the organic soil matter. This hypothesis is in line with Van Groenigen et al. (2010) study which has reported that, after twenty years of no-till operations, the soil organic carbon increases by $16 \%$ in humid temperate regions and by $10 \%$ in dry temperate regions, compared to conventional seedling. In our study, the soil organic matter and organic carbon contents showed a tendency increase of $29 \%$ in no-till plots (Figure 8). Contents of soil organic matter (SOM) and total nitrogen remained low for respectively the no-till and conventional seedling systems respectively (Figure 6), which reflects soil poor fertility.

This situation could be explained by the low amounts of cereal crop residues to return to the soil. In North Africa, often cereal residues are used as a pasture source for sheep farming (Lahmar \& Ruellan, 2007). The monoculture (wheat/wheat), applied in our experiment, implies a slow-down of organic matter mineralization in comparison to crop rotation (cereal/legume).

An increase in yields observed in our experiment during the first three years of the no-tillage farming system (Figure 9), is consistent with the results reached by Angar et al. (2010), who have reported that durum wheat yields, during ten years of no tillage in a sub-humid zone of Tunisia, increased by $0.8 \mathrm{t} / \mathrm{ha}$, compared to conventional seedling. In a semi-arid zone, this difference was lower $(0.35 \mathrm{t} / \mathrm{ha})$, and it reached $0.7 \mathrm{t} / \mathrm{ha}$ in the upper semi-arid areas.

Consequently, one may say that late sowing (12/01/2012 and 09/01/2013) (Table 3) during the last two years of experimentation does not allow a good early planting of the crop and limits the $\mathrm{H}_{2} \mathrm{O}$ intake of the rainfall during the autumn season. These effects are to be added to the low temperatures of January and February that occur just after sowing, which prevents an adequate growth of plants by affecting their physiological development of meristems (Chassot et al., 2002). Chapman et al. (2001) have pointed the negative effect of low temperatures on the rate of mineralization of nitrogen in the soil. These factors together seem to be at the origin of the suppression of the positive effect of the no-till farming system during these two agricultural campaigns. 


\section{Conclusion}

The results of our study demonstrated that the no-till farming system has a positive impact on the AMF symbiosis, as demonstrated by the increase of AMF biomass in the soil and the arbuscular root colonization percentages. Besides, in conventional seedling, root colonization was characterized by a strong presence of vesicles. The biodiversity of AMF was improved by the relative abundance of six families of Glomales and the emergence of new AMF species. These results are in favor of the adoption of the no-till system as an approach to restore the microbiome in agro-systems disturbed by tillage.

The aridity of our study area, the monoculture and the presence of a high level of soil limestone facilitated the predominance of the AMF root colonization over the other endophytic fungi.

For the sake of productivity and sustainability, it is desirable that a similar study be carried out using co-culture of wheat/legume rotation to improve nitrogen and soil organic matter levels. An economic study is also needed to assess the impact of no tillage technique on the cost of production and profitability of the crop.

\section{Acknowledgements}

This work is part of the Algerian-Australian Research and Cooperation Project (CANA) (Conservation Agriculture North Africa). The experimental trials were conducted on rainfed cereals in semi-arid areas, notably at the Experimental Station of the Technical Institute of Field Crops (ITGC) of Sétif, located in eastern Algeria. Our gratitude goes to the technical team of ITGC Sétif for the installation and conduct of field trials. We are grateful to Mrs Y. Dalpé and Mrs K. Bencherif for their valuable contribution to the identification of mycorrhizal spores. We also wish to thank Mrs N. Deguiche (ITGC) and Mr R. Bradai (INRA) for having carried out the analysis of organic matter and mineral nitrogen of the soil.

\section{References}

Alguacil, M. M., Lumini, E., Roldan, A., Salinas-Garcia, J. R., \& Bonfan, P. (2008). The impact of tillage practices on arbuscular mycorrhizal fungal diversity in subtropical crops. Ecological Applications, 18(2), 527-536. https://doi.org/10.1890/07-0521.1

Alvarez, C. R., Alvarez, R., Rosa, C., \& Roberto, A. (2000). Short-term effects of tillage systems on active soil microbial biomass. Biology and Fertility of Soils, 31(2), 157-16. http://doi.org/10.1007/s003740050639

Angar, H., Ben Haj Salah, H., \& Ben-Hammouda, M. (2011). Semis direct et semis conventionnel en Tunisie: Les résultats agronomiques de 10 ans de comparaison. In H. Bouzerzour, H. Irekti, \& B. Vadon (Eds.), Options Méditerranéennes: Série A, Séminaires Méditerranéens (No. 96 pp. 53-59). Rencontres Méditerranéennes du Semis Direct in Zaragoza: CIHEAM/ATU-PAM/INRAA/ITGC/FERT. http://om.ciheam.org/article.php?IDPDF=801418

Arabi, M., \& Roose, E. (1989). Influence du système de production et du sol sur l'érosion et le ruissellement en nappe en milieu montagnard méditerranéen (station d'Ouezra, Algérie). Réseau d’Erosion (Bulletin No. 9). Montpellier, ORSTOM.

Aslam, T., Choudhary, M. A., \& Saggar, S. (1999). Tillage impacts on soil microbial biomass C, N and P, earthworms and agronomy after two years of cropping following permanent pasture in New Zealand. Soil and Tillage Research, 51(1-2), 103-111. https://doi.org/10.1016/S0167-1987(99)00032-X

Aubert, G. (1978). Méthodes d'analyses des sols (p. 189). Edit C.R.D.P. Marseille.

Babujia, L. C., Hungria, M., Franchini, J. C., \& Brookes, P. C. (2010). Microbial biomass and activity at various soil depths in a Brazilian oxisol after two decades of no-tillage and conventional tillage. Soil Biology and Biochemistry, 42(12), 2174-2181. https://doi.org/10.1016/j.soilbio.2010.08.013

Bago, B., Pfeffer, P. E., Abubaker, J., Jun, J., Allen, J. W., Brouillette, J., Shachar-Hill, Y. (2003). Carbon export from arbuscular mycorrhizal roots involves the translocation of carbohydrate as well as lipid. Plant Physiology, 131, 1496-1507. https://doi.org/10.1104/pp.102.007765

Bago, B., Zipfel, W., Williams, R. M., Jun, J., Arreola, R., Lammers, P. J., Shachar-Hill, Y. (2002). Translocation and utilization of fungal storage lipid in the arbuscular mycorrhizal symbiosis. Plant Physiology, 128, 108-124. https://doi.org/10.1104/pp.010466

Balestrini, R., Lumini, E., Borriello, R., \& Bianciotto, V. (2015). Plant-soil biota interactions. In E. A. Paul (Ed.), Soil Microbiology, Ecology and Biochemistry (pp. 311-338). London: Academic Press. https://doi.org/10.1016/b978-0-12-415955-6.00011-6 
Balota, E. L., Colozzi Filho, A., Andrade, D. S., \& Dick, R. P. (2004). Long-term tillage and crop rotation effects on microbial biomass and $\mathrm{C}$ and N mineralization in a Brazilian Oxisol. Soil and Tillage Research, 77(2), 137-145. https://doi.org/10.1016/j.still.2003.12.003

Batouches, S., \& Labiod, H. (1991). Les sols des hautes plaines sétifiennes, inventaire, analyse et synthèse des études pédologiques réalisées dans cette région de 1965 à 1985: Esais de thématisation (p. 133). Mém. Ing. Univ. Sétif.

Bellotti, B., \& Rochecouste, J. F. (2014). The Development of Conservation Agriculture in Australia Farmers as innovators. International Soil and Water Conservation Research, 2(1), 1-34. https://doi.org/10.1016/S20956339(15)30011-3

Berner, A., Hildermann, I., Fließbach, A., Pfiffner, L., Niggli, U., \& Mader, P. (2008). Crop yield and soil fertility response to reduced tillage under organic management. Soil \& Tillage Research, 101, 89-96. https://doi.org/10.1016/j.still.2008.07.012

Biermann, B., \& Linderman, R. G. (1983). Use of vesicular-arbuscular mycorrhizal roots, intraradical vesicles and extraradical vesicles as inoculum. New Phytologist, 95, 97-105. https://doi.org/10.1111/j.1469-8137. 1983.tb03472.x

Boddington, C. L., \& Dodd, J. C. (2000). The effect of agricultural practices on the development of indigenous arbuscular mycorrhizal fungi. I. Field studies in an Indone-sian ultisol. Plant and Soil, 218, 137-144. https://doi.org/10.1023/A:1014966801446

Bourgeois, E., Dequiedt, S., Lelièvre, M., van Oort, F., Lamy, I., Maron, P. A., \& Ranjard, L. (2015). Positive effect of the Miscanthus bioenergy crop on microbial diversity in wastewater-contaminated soil. Environmental Chemistry Letters, 13(4), 495-501. http://doi.org/10.1007/s10311-015-0531-5

Bremner, J. M., \& Mulvaney, C. S. (1982). Total nitrogen. In A. L. Pages, R. H. Miller, \& D. R. Keeney (Eds.), Methods of soil analysis (2nd ed., Agronomy No. 9, pp. 595-622). ASA and SSSA, Madison, WI.

Bruelle, G., Affholder, F., Abrell, T., Ripoche, A., Dusserre, J., Naudin, K., ... Scopel, E. (2017). Can conservation agriculture improve crop water availability in an erratic tropical climate producing water stress? A simple model applied to upland rice in Madagascar. Agricultural Water Management, 192, $281-293$. https://doi.org/10.1016/j.agwat.2017.07.020

Brundrett, M., Bougher, N., Dell, B., Grove, T., \& Malajczuk, N. (1996). Working with Mycorrhizas. Forestry and Agriculture (Monograph 32, 374). AClAR.

Cardoso, I. M., Boddington, C., Jansen, B. H., Oenemaet, O., \& Kuyper, T. W. (2003). Distribution of Mycorrhizal fungal spores in soils under agroforestry and monoculturalcoffee systems in Brazil. Agroforestry Systems, 58, 33-43. https://doi.org/10.1023/A:1025479017393

Castillo, C. G., Puccio, F., Morales, D., Borie, F., \& Sieverding, E. (2012). Early arbuscular mycorrhiza colonization of wheat, barley and oats in Andosols of southern Chile. Journal of Soil Science and Plant Nutrition, 12(3), 511-524. https://doi.org/10.4067/S0718-95162012005000012

Cavalcante, U. M. T., Goto, B. T., \& Maia, L. C. (2009) Aspectos da simbiose micorrízica arbuscular. An Acad Pe Cien Agr, 5(6), 180-208. https://doi.org/10.1007/s00572-015-0636-5

Celik, I., Barut, Z. B., Ortas, I., Gok, M., Demirbas, A., Tulun, Y., \& Akpinar, C. (2011). Impacts of different tillage practices on some soil microbiological properties and crop yield under semi-arid Mediterranean conditions. International Journal of Plant Production, 5(3), 237-254.

Chagnon, P. L., Bradley, R. L., Maherali, H., \& Klironomos, J. N. (2013). A trait-based framework to understand life history of mycorrhizal fungi. Trends in Plant Science, 18, 484-491. https://doi.org/10.1016/j.tplants.2013.05.001

Chapman, P. J., Williams, B. L., \& Hawkins, A. (2001). Influence of temperature and vegetation cover on soluble inorganic and organic nitrogen in a Spodosol. Soil Biology \& Biochemistry, 33, 1113-1121. https://doi.org/10.1016/S0038-0717(01)00017-7

Chassot, A. (2000). Early growth of roots and shoots of maize as affected by tillage-induced changes in soil physical properties (p. 89, PhD Thesis, ETH Zürich). https://doi.org/10.3929/ethz-a-004132762

Clay, K. (2004). Fungi and the food of the gods. Nature, 427, 401-402. https://doi.org/10.1038/427401a 
Coutinho, E. S., Fernandes, G. W., Berbara, R. L. L., Valério, H. M., \& Goto, B. T. (2015). Variation of arbuscular mycorrhizal fungal communities along an altitudinal gradient in rupestrian grasslands in Brazil. Mycorrhiza, 25(8), 627-638. https://doi.org/10.1007/s00572-015-0636-5

Curaqueo, G., Acevedo, E., Cornejo, P., Seguel, A., Rubio, R., \& Borie, F. (2010). Tillage Effect on Soil Organic Matter, Mycorrhizal Hyphae and Aggregates in a Mediterranean Agroecosystem. R.C. Suelo Nutr. Veg., 10(1), 12-21. https://doi.org/10.4067/S0718-27912010000100002

Dalpe, Y. (1993).Vesicular-arbuscular mycorrhiza. In M. R. Carter (Ed.), Soil sampling and methods of analysis (pp. 287-301). Canadian Society for Soil Science, Lewis, Boca Raton, Fla.

Daniell, T. J., Husband, R., Fitter, A. H., \& Young, J. P. W. (2001). Molecular diversity of arbuscular mycorrhizal fungi colonizing arable crops. FEMS Microbiology Ecology, 36, $203-209$. https://doi.org/10.1111/j.1574-6941.2001.tb00841.x

De la Providencia, I. E., de Souza, F. A., Fernández, F., Séjalon Delmas, N., \& Declerck, S. (2005). Arbuscular mycorrhizal fungi reveal distinct patterns of anastomosis formation and hyphal healing mechanisms between different phylogenic groups. New Phytologist, 165, 261-271. https://doi.org/10.1111/j.1469-8137. 2004.01236.x

De Souza, F., Dalpé, Y., Declerck, S., Providencia, I. de la, \& Séjalon-Delmas, N. (2005). Life History strategies in Gigasporaceae: Insight from monoxenic culture. In S. Declerck, D. Strullu, \& J. A.Fortin (Eds.), In vitro culture of mycorrhizas (pp. 74-94). Heidelberg, Springer-Verlag. https://doi.org/10.1007/3-540-27331-X_5

Diallo, A. T., Samba, P. I., \& Ducousso, M. (1999). Arbuscular mycorrhizal fungi in the semi-arid areas of Senegal. European Journal of Soil Biology, 35(2), 65-75. https://doi.org/10.1016/S1164-5563(99)00110-7

Djebaili, S. (1984). Steppes algériennes: Phytosociologie et écologie (p. 177). Office des Publications Universitaires, Alger.

Drijber, R. A., Doran, J. W., Parkhurst, A. M., \& Lyon, D. J. (2000). Changes in soil microbial community structure with tillage under long-term wheat-fallow management. Soil Biology and Biochemistry, 32(10), 1419-1430. https://doi.org/10.1016/S0038-0717(00)00060-2

Duponnois, R., Hafidi, M., Wahbi, S., Sanon, A., Galiana, A., Baudoin, E., Bally, R. (2012). La symbiose mycorhizienne et la fertilité des sols dans les zones arides: un outil biologique sous-exploité dans la gestion des terres de la zone sahélo-saharienne. In A. Dia \& D. Robin (Eds.), La Grande Muraille Verte: Capitalisation des recherches et valorisation des savoirs locaux (pp. 351-369). Marseille: IRD.

FAO. (2003). Economie de l'agriculture de conservation (p. 77). Service de la gestion des terres et de la nutrition des plantes. Division de la mise en valeur des terres et des eaux. Rome, Italy.

Fontaine, S., Mariotti, A., \& Abbadie, L. (2003). The priming effect of organic matter: A question of Microbial competition? Soil Biology and Biochemistry, 35(6), 837-843. http://doi.org/10.1016/S0038-0717(03) 00123-8

Freitas, P. L., \& Landers, J. N. (2013). The transformation of agriculture in Brazil through development and adoption of Zero Tillage Conservation Agriculture. International Soil and Water Conservation Research, 2(1), 35-46. https://doi.org/10.1016/S2095-6339(15)30012-5

Frostegård, Å., Tunlid, A., \& Bååth, E. (1991). Microbial biomass measured as total lipid phosphate in soils of different organic content. J. Microbiol. Methods, 14, 151-163. https://doi.org/10.1016/0167-7012(91) 90018-L

Garbaye, J. (2013). La symbiose mycorhizienne, une association entre les plantes et les champignons. Editions Quae.

García-Orenes, F. A., Morugan-Coronado, R., \& Zornoza Scow, K. (2013). Changes in Soil Microbial Community Structure Influenced by Agricultural Management Practices in a Mediterranean Agro-Ecosystem. PLoS ONE, 11(3), e0152958. https://doi.org/10.1371/journal.pone.0152958

Gavito, M. E., Jakobsen, I., Mikkelsen, T. N., \& Mora, F. (2019). Direct evidence for modulation of photosynthesis by an arbuscular mycorrhizainduced carbon sink strength. New Phytol., 223(2), 896-907. https://doi.org/10.1111/nph.15806

Gerdeman, J. W., \& Nicolson, T. H. (1963). Spore of mycorrhizalendogone species extracted from soil by wet sieving and decanting. Trans. Brit. Mycol. Soc., 46, 235-244. https://doi.org/10.1016/S0007-1536(63) 80079-0 
Gerdmann, J. W., \& Trappe, J. M. (1974). The Endogonaceae in the Pacific Northwest. Myc. Memoir., 5, 1-76.

Giovannetti, M., Azzolini, D., \& Citernesi, A. S. (1999) Anastomosis formation and nuclear and protoplasmic exchange in arbuscular mycorrhizal fungi. Applied and Environmental Microbiology, 65, 5571-5575. https://doi.org/10.1128/AEM.65.12.5571-5575.1999

Grignac, P. (1986). Contraintes de l'environnement et élaboration du rendement dans la zone méditerranéenne française. L"élaboration du rendement des cultures céréalières (pp. 196-207). Colloque Franco Romain, Clermont-Ferrant.

Halitim, A. (1988). Sols des régions arides (p. 384). Office des Publications Universitaires, Alger.

Hart, M. M., \& Reader, R. J. (2004). Do arbuscular mycorrhizal fungi recover from soil disturbance differently? Tropical Ecology, 45(1), 97-111.

IJdo, M., Schtickzelle, N., Cranenbrouck, S., \& Declerck, S. (2010). Do arbuscular mycorrhizal fungi with contrasting life-history strategies differ in their responses to repeated defoliation? FEMS Microbiology Ecology, 72, 114-122. https://doi.org/10.1111/j.1574-6941.2009.00829.x

Jansa, J., Mozafar, A., Anken, T., Ruh, R., Sanders, I. R., \& Frossard, E. (2002). Diversity and structure of AMF communities as affected by tillage in a temperate soil. Mycorrhiza, 12, 225-234. https://doi.org/10.1007/s00572-002- 0163-z

Jansa, J., Mozafar, A., Kuhn, G., Anken, T., Ruh, R., Sanders, I. R., \& Frossard, E. (2003). Soil tillage affects the community structure of mycorrhizal fungi in maize roots. Ecological Applications, 13, $1164-1$. https://doi.org/10.1890/1051-0761(2003)13[1164:STATCS]2.0.CO;2

Jansa, J., Wiemken, A., \& Frossard, E. (2006). The effects of agricultural practices on arbuscular Mycorrhizal fungi. The Geological Society of London, Special Publications, 266, 89-115. https://doi.org/10.1144/GSL.SP.2006.266.01.08

Jasper, D. A., Abbott, L. K., \& Robson, A. D. (1991). The effect of soil disturbance on vesicular Arbuscular mycorrhizal fungi in soil from different vegetation types. New Phytologist, 118, 471-476. https://doi.org/10.1111/j.1469-8137.1991.tb00029.x

Johansson, J. F., \& Paul, L. R. (2004). Finlay RD Microbial interactions in the mycorrhizosphere and their significance for sustainable agriculture. FEMS Microbiology Ecology, 48, 1-13. https://doi.org/10.1016/j.femsec.2003.11.012

Johnson, N. C., Zak, D. R., Tilman, D., \& Pfleger, F. L. (1991). Dynamics of vesicular-arbuscular mycorrhizaeduring old field succession. Oecologia, 86, 349-358. https://doi.org/10.1007/BF00317600

Kabir, Z. (2005). Tillage or no-tillage: Impact on mycorrhizae. Can. J. Plant Sci., 85, 23-29. https://doi.org/10.4141/P03-160

Kabiri, V., Raiesi, F., \& Ghazavi, M. A. (2016). Tillage effects on soil microbial biomass, SOM mineralization and enzyme activity in a semi-arid Calcixerepts. Agriculture, Ecosystems\& Environment, 232(16), 73-84. https://doi.org/10.1016/j.agee.2016.07.022

Kaci, M., Habi, M., \& Morsli, B. (2017). Application of universal soil loss equation (USLE) model to estimate water erosion by GIS system and remote sensing: catchment area of oued Rhiou (Watershed of Cheliff), Algeria. Geo-Eco-Trop., 41(3), 503-518.

Karkour, L. (2012). La dynamique des mauvaises herbes sous l'effet des pratiques culturales dans la zone des plaines intérieures. Mémoire d'obtention du diplôme de Magister Option, Production Végétale et Agriculture de Conservation, Université Ferhat Abbas Sétif Faculté des Sciences de la Nature et de la Vie.

Karuma, A., Mtakwa, P., Amuri, N., Gachene, C. K., \& Gicheru, P. (2014). Tillage Effects on Selected Soil Physical Properties in a Maize-Bean Intercropping System in Mwala District, Keny. International Scholarly Research Notices, Article ID 497205. https://doi.org/10.1155/2014/497205

Keenen, M. L., Mack, A., \& Rudgers, A. (2007). Balancing multiple mutualists: Asymmetric interactions among plants, arbuscular mycorrhizal fungi, and fungal endophytes (p. 11). Publication Dept. of Biology, Indiana Univ, Bloomington, IN, USA. https://doi.org/10.1111/j.2007.0030-1299.15973.x

Keymer, A., Pimprikar, P., Wewer, V., Huber, C., Brands, M., Bucerius, S. L., Gutjahr, C. (2017). Lipid transfer from plants to arbuscular mycorrhiza fungi. eLife, 6, e29107. https://doi.org/10.7554/eLife. 29107.001 
Labreuche, J. C., Le Souder, P., Castillon, J. F., Oury, B., Real, J. C., Germon, S., \& Tourdonnet, D. (2007). Evaluation des impacts environnementaux des Techniques Culturales Sans Labour en France (p. 400). ADEME-ARVALIS Institut du végétal-INRA-APCA-AREAS-ITB CETIOMIFVV. https://doi.org/10.1684/agr.2007.0119

Lahmar, R., \& Bouzerzour, H (2011). Du mulch terreux au mulch organique pour assurer une transition Vers l'agriculture durable dans les hautes plaines sétifiennes. In H. Bouzerzour, H. Irekti, \& B. Vadon (Eds.), Options Méditerranéennes: Série A, Séminaires Méditerranéens (No. 96, pp. 99-106). Rencontres Méditerranéennes du Semis Direct Zaragoza: CIHEAM/ATU-PAM/INRAA/ITGC/FERT.

Lahmar, R., \& Ruellan, A. (2007). Dégradation des sols et stratégies coopérative en Méditerranée. La pression sur les ressources naturelles et les stratégies de développement durable (Vol. 16, pp. 318-323). Dans: Cahiers Agricultures.

Lienhard, P., Terrat, S., Prévost-Bouré, N. C., \& Nowak, V. (2014). Régnier T, Sayphoummie S et Ranjard L Pyrosequencing evidences the impact of cropping on soil bacterial and fungal diversity in Laos tropical grassland. Agronomy for Sustainable Development, 34(2), 525-533. http://doi.org/10.1007/s13593-0130162-9

Lyon, D. J., Boa, F., \& Arkebauer, T. J. (1996). Water-yield relations of several spring-planted dry land Crops following winter-wheat. J. Prod. Agric., 8, 281-286. https://doi.org/10.2134/jpa1995.0281

Madejon, E., Moreno, F., Murillo, J. M., \& Pelegrin, F. (2007). Soil biochemical response to long-term conservation tillage under semi-arid Mediterranean conditions. Soil Till. Res., 94, $346-352$. http://doi.org/10.1016/j.still.2006.08.010

Maherali, H., \& Klironomos, J. N. (2007). Influence of Phylogeny on Fungal Community Assembly and Ecosystem Functioning. Science, 316, 1746-1748. http://doi.org/10.1126/science.1143082

Mandyam, K., \& Jumpponen, A. (2005). Seeking the elusive function of the root-colonising dark septate endophytic fungi. Studies in Mycology, 53, 173-189. https://doi.org/10.3114/sim.53.1.173

Mandyam, K., \& Jumpponen, A. (2008). Seasonal and temporal dynamics of arbuscular mycorrhizal and dark septate endophytic fungi in a tall grass prairie ecosystem are minimally affected by nitrogen enrichment. Mycorrhiza, 18, 145-155. http://doi.org/10.1007/s00572-008-0165-6

McGonigle, T. P., Miller, M. H., Evans, D. G., Fairchild, G. L., \& Swan, J. (1990). A new method which gives and objective measure of colonization of roots by vesicular arbuscular fungi. New Phytologist, 115, 1569-1574. https://doi.org/10.1111/j.1469-8137.1990.tb00476.x

Meglouli, H., Lounès-Hadj Sahraoui, A., Magnin-Robert, M., Tisserant, B., Hijri, M., \& Fontaine, J. (2018). Arbuscular mycorrhizal inoculum sources influence bacterial, archaeal, and fungal communities' structures of historically dioxin/furan-contaminated soil but not the pollutant dissipation rate. Mycorrhiza, $28(7), 635$. http://doi.org/10.1007/s00572-018-0852-x

Mrabet, R. (2001b). Le Semis Direct: Une technologie avancée pour une Agriculture durable au Maroc. Bulletin de Transfert de Technologie en Agriculture MADREF-DERD (No. 76, p. 4). Retrieved from http://agriculture.ovh.org

Nadji, W., Belbekri, N., Ykhlef, N., \& Djekoun, A. (2017). Diversity of arbuscular mycorrhizal fungi of durum Wheat (Triticum durum Desf.) fields of the East of Algeria. J. Agric. Sci, 9, 117. http://doi.org/10.5539/jas.v9n3p117

Oehl, F., Sieverding, E., Ineichen, K., Mader, P., Boller, T., \& Wiemken, A. (2003). Impact of land use intensity on the species diversity of arbuscular mycorrhizal fungi in agro-ecosystems of central Europe. Applied and Environmental Microbiology, 69, 2816-28. http://doi.org/10.1128/AEM.69.5.2816-2824.2003

Oehl, F., Sieverding, E., Mader, P., Dubois, D., Ineichen, K., Boller, T., \& Wiemken, A. (2004). Impact of long-term conventional and organic farming on the diversity of arbuscular mycorrhizal fungi. Oecologia, 138, 574-583. http://doi.org/10.1007/s00442-003-1458-2

Olsson, P. A., Baêaêth, E., Jakobsen, I., \& Soèderstroèm, B. (1995). The use of phospholipid and neutral lipid fatty acids to estimate biomass of arbuscular mycorrhizal fungi. Mycological Research, 99, 623-629. https://doi.org/10.1016/S0953-7562(09)80723-5 
Olsson, P. A., Francis, R., Read, D. J., \& Söderström, B. (1998). Growth of arbuscular mycorrhizal mycelium in calcareous dune sand and its interaction with other soil microorganisms as estimated by measurement of specific fatty acids. Plant and Soil, 201(1), 9-16. https://doi.org/10.1023/A:1004379404220

Olsson, P. A., Thingstrup, J. I., \& Bââth, E. (1999). Estimation of the biomass of arbuscular mycorrhizal fungi in a linseed field. Soil Biology and Biochemistry, 31, 1879-1887. https://doi.org/10.1016/S0038-0717 (99)00119-4

Peterson, R. L., Wagg, C., \& Pautler, M. (2008). Associations between microfungal endophytes and roots: Do structural featuresindicate function? Botany, 86, 445-456. http://doi.org/10.1139/B08-016

Phillips, J. M., \& Hayman, D. S. (1970). Improved procedures for clearing roots and staining parasitic and vesicular-arbuscular rnycorrhizal fungi for rapid assessment of infection. Trans. Br. Mycol. Soc., 55, 158-161. https://doi.org/10.1016/S0007-1536(70)80110-3

Rouabhi, A., Laouar, A., Mekhlouk, A., \& Dhehibi, B. (2019). Socioeconomic Assessment of No-Till in Wheat Cropping System: A Case Study in Algeria. New Medit, 18(1), 53-64. https://doi.org/10.30682/nm1901e

Rodriguez, R. J., Redman, R. S., \& Joan, M. H. (2004). The role of fungal symbioses in the Adaptation of plants to high stress environments. Mitigation and Adaptation Strategies for Global Change, 9, 261-272. http://doi.org/10.1023/B:MITI.0000029922.31110.97

Roldan, A., Salinas-Garcia, J. R., Alguacil, M. M., \& Caravaca, F. (2007). Changes in soil sustainability indicators following conservation tillage practices under subtropical maize and bean crops. Soil and Tillage Research, 93, 273-282. https://doi.org/10.1016/j.still.2006.05.001

Schalamuk, S., Velazquez, S., Chidichimo, H., \& Cabello, M. (2006). Fungal spore diversity of arbuscular Mycorrhizal fungi associated with spring wheat: Effects of tillage. Mycologia, 98(1), 16-22. http://doi.org/10.3852/mycologia.98.1.16

Soka, G., \& Ritchie, M. (2015). Arbuscular mycorrhizal symbiosis, ecosystem processes and Environmental changes in tropical soils. Applied Ecology and Environmental Research, 13(1), 229-245. http://doi.org/10.15666/aeer/1301_229245

Staddon, P. L., \& Fitter, A. H. (2001). The differential vitality of intraradical mycorrhizal structures and its implications. Soil Biology \& Biochemistry, 33, 129-132. http://doi.org/10.1046/j.1365-2486.2003.00593.x

Strullu, D. G. (1991). Les mycorhizes des arbres et des plantes cultivées (p. 250). Lavoisier, Paris.

Trépanier, M., Bécard, G., Moutoglis, P., Willemot, C., Gagné, S., Avis, T. J., \& Rioux, J. A. (2005). Dependence of arbuscular-mycorrhizal fungi on their plant host for palmitic acid synthesis. Applied and Environmental Microbiology, 71, 5341-5347. http://doi.org/10.1128/AEM.71.9.5341-5347.2005

Tuzzin de Moraes, M., Debiasi, H., Carlesso, R., Cezar Franchini, J., Rodrigues da Silva, V., \& Bonini da Luz, F. (2016). Soil physical quality on tillage and cropping systems after two decades in the subtropical region of Brazil. Soil and Tillage Research, 155, 351-362. http://doi.org/10.1016/j.still.2015.07.015

Van der Heijden, M. G. A., \& Sanders, I. R. (2003). Mycorrhizal Ecology. Springer-Verlag Berlin Heidelberg GmbH. https://doi.org/10.1007/978-3-540-38364-2

Van Groenigen, K. J., Bloem, J., Bååth, E., Boeckx, P., Rousk, J., Bodé, S., \& Jones, M. B. (2010). Abundance production and stabilization of microbial biomass under conventional and reduced tillage. Soil Biology and Biochemistry, 42(1), 48-55. https://doi.org/10.1016/j.soilbio.2009.09.023

Vega, F. E., Posada, F., Aime, M. C., Ripoll, M. P., Infante, F., \& Rehner, S. A. (2008). Entomopathogenic fungal endophytes. Biological Control, 46, 72-82. http://doi.org/10.1007/978-90-481-3966-8_9

Vega, J., Cristina, A., \& Fonturbel, T. (2015). Comparing the effectiveness of seeding and mulching + seeding in reducing soil erosion after a high severity fire in Galicia (NW Spain). Ecological Engineering, 74, $206-212$. https://doi.org/10.1016\%2Fj.ecoleng.2014.10.019

Vergara, C., Karla, E. C. A., Luiziene, S. A., Sônia, R. de S., Leandro, A. S., Gustavo, R. X., Jerri, E. Z. (2018). Contribution of dark septate fungi to the nutrient uptake and growth of rice plants. Brazilian Journal of Microbiology, 4(9), 67-78. https://doi.org/10.1016/j.bjm.2017.04.010

Voets, L., de la Providencia, I. E., \& Declerck, S. (2006). Glomeraceae and Gigasporacea differ in their ability to form hyphal networks. New Phytologist, 172, 185-188. https://doi.org/10.1111/j.1469-8137.2006.01873.x 
Wang, Y, Vestberg, M., Walker, C., Hurmer, T., Zhang, X., \& Lindström, K. (2008). Diversity and infectivity of arbuscular mycorrhizal fungi in agricultural soils of the Sichuan Province of mainland China. Mycorrhiza, 18, 59-68. https://doi.org/10.1016\%2Fj.ecoleng.2014.10.019

Wu, Q. S. (2017). Arbuscular Mycorrhizas and Stress Tolerance of Plants (Library of Congress Control Number: 2017936364). http://doi.org/10.1007/978-981-10-4115-0

Yu, J., Xue, Z., He, X., Liu, C., \& Steinberger, Y. (2017). Shifts in composition and diversity of arbuscular mycorrhizal fungi and glomalin contents during revegetation of desertified semiarid grassland. Applied Soil Ecology, 115, 60-67. https://doi.org/10.1016/j.apsoil.2017.03.015

Yuan, Z. L., Llin, F. C., Zhang, C. L., \& Kubicek, C. P. (2010). A new species of Harpophora (Magnaporthaceae) recovered from healthy wildrice (Oryza granulata) roots, representing a novel member of abeneficial dark septate endophyte. FEMS Microbiol Lett., 307, 94-101. https://doi.org/10.1111/j.1574-6968.2010. 01963.x

Zeghouane, O., Abdellaoui, Z., \& El Mourid, M. (2015). L'agriculture de conservation: Introduction et perspectives de développement du semis direct dans les systèmes de production céréaliers, une nouvelle expérience en Algérie. Collaboration entre ITGC, ICARDA, ACIAR. Retrieved from http://om.ciheam.org/article.php?IDPDF=6600104

Zeghouane, O., Bouzerzour, H., Houassine, D., Makhlouf, M., Abdellaoui, Z., \& Ameroun, R. (2011). La situation du programme de développement de l'agriculture de conservation en Algérie. Revue Céréaliculture $n^{\circ} 57$ (pp. 19-31). Institut Technique des Grandes Cultures.

\section{Copyrights}

Copyright for this article is retained by the author(s), with first publication rights granted to the journal.

This is an open-access article distributed under the terms and conditions of the Creative Commons Attribution license (http://creativecommons.org/licenses/by/4.0/). 